\title{
Early Modern Ottoman Science: A New Materialist Framework
}

\author{
B. Harun Küçük \\ University of Pennsylvania \\ kucuk@sas.upenn.edu
}

\begin{abstract}
This article is a programmatic statement advocating a materialist reading of early modern Ottoman science. I argue that a history of science that is sensitive to the material life of Ottoman subjects will help scholars cut through the unwarranted vocabulary of "Islamic science," "Westernization" or "Ottoman civilization." Two mini studies substantiate the programmatic claims. The first study presents a preliminary reinterpretation of the earliest mention of Copernican astronomy in Turkish, dated 1662. The second study reveals the maritime and mercantile genealogy of the eighteenth-century Ottoman prayer compass.
\end{abstract}

\section{Keywords}

Scientific Revolution - Ottoman Empire - magnetism - astronomy - calendar historical materialism

\section{Introduction}

In the early 1670s Hayatizade Mustafa Feyzi (d.1692), born Moshe ben Raphael Abravanel, finished his Five Treatises Treating Difficult Diseases. ${ }^{1}$ The first two treatises-very popular ones with almost eighty extant manuscript copies,

* I would like to thank Robert Westman, Lissa Roberts, A. Tunç Şen and the participants of the Beyond the Scientific Revolution workshop for their valuable input.

1 The copy I used is Süleymaniye ms Hekimoglu 565 . For the biography of Hayatizade, see Cengiz Şişman, "Hayatizade Mustafa Efendi (Moshe ben Rafael Abravanel), the Physician-in-Chief 
including ones in Armenian script—dealt with hypochondria and melancholy hypochondria. While one disease afflicted young, poor men whose diet consisted of bread and wine, the other was prevalent among coffee-drinking, gameeating men of a certain age who also spent a lot of time reading. Hayatizade was following and testing Daniel Sennert's claims as he was writing these treatises, but where did the diseases come from? Did someone also translate these famously English diseases into popular Ottoman afflictions?

The puzzle Hayatizade's work presents is unique and involves the mass conversion of Jews to Islam, but it also points to an important question for early modern Ottoman science: What was the relationship between the material life of the Ottomans and their science? Science has material components, both physical and monetary, which do not play as great a role as they should in our understanding of early modern science in Muslim polities. The omission of this material component has contributed to "chauvinistic gerrymandering," to borrow Kapil Raj's phrase, in the history of "Islamic science."

In proposing a novel historiographical framework, I will be following what I call the new materialist historiography of early modern science. The volumes I have in mind are The Mindful Hand, Relocating Modern Science and Matters of Exchange. This historiography defines science as a mixture of craft knowledge and scholarly knowledge that contributed to state-building and emerging commercial capitalism across the globe. ${ }^{3}$ By emphasizing the connections between economic activity, political action and science, it brings the history of science into the fold of Braudelian history. This new materialist historiography differs from classical Marxism of Edgar Zilsel and Boris Hessen because it is global in scope, gradualist in temperament and flexible in its understanding of class, interest and profit. It is an important antidote to the rupturist legacy of Eurocentric historiography, with its interests in purely conceptual revolutions and great divergences. ${ }^{4}$

of the Ottoman Palace: Marrano Legacy, Ottoman Medicine and the Sabbatean Movement," in Transcending Diaspora (İstanbul, 2016).

2 On chauvinistic misrepresentation of pre-modern Islamic science, see Sonja Brentjes's scathing review of the exhibit and the book, "1001 Inventions: The Enduring Legacy of Muslim Civilization..." Aestimatio 10 (2013): 119-153.

3 Lissa Roberts, Simon Schaffer and Peter Dear, eds. The Mindful Hand (Amsterdam, 2007); Kapil Raj, Relocating Modern Science (New York, 2007); Harold Cook, Matters of Exchange (New Haven, 2007).

4 Flanking this position are issues of prior globalities as reflected in Pamela Smith's Itineraries of Materials, Recipes, Techniques and Knowledge across Eurasia working group at the Max Planck Institute for the History of Science, and also limits of early modern globalization. 
There is a simple argument to be made for the Ottoman Empire from this perspective: if the Ottoman Empire flourished in the early modern period, occupied an important role in the Asia-Europe land and sea routes well into the eighteenth century, and felt the effects of the integration of early modern world economy as much as any other polity did, its science must also show signs of change in nature and scope. Such changes would not be solely or even at all philosophical or Western, strictly speaking. We can easily trivialize — and to a certain extent, should trivialize - canonical examples of "Westernization," which would include the rise of Ottoman Paracelsianism and the fashioning of a Sultanic press after the French Imprimerie Royale. These were, after all, merely conditioned responses of unknown efficacy to crises that haunted the Ottoman Empire in general and Istanbul in particular. Far more difficult to trivialize are the widespread circulation of drug recipes, which invariably involved rare and imported ingredients, and the attending empiricist practices; the various coinage, tax and calendar reforms of the seventeenth and the eighteenth centuries, all of which required very advanced numeracy; built and rebuilt urban structures and infrastructures; the ever-changing gunpowder mills, dockyards and foundries; or the massive popularity of coffee and tobacco in seventeenth-century Istanbul. What is also not so easy to trivialize is El-Hac Mehmed Efendi (fl.1720s) who, as a wealthy apothecary and the elected Sheik of Istanbul's apothecaries, routinely filed complaints about poor commoners, ran a counterfeit coin operation in his own house and dodged justice for many years. ${ }^{5}$ That is, natural knowledge permeated all facets of material life for good or ill as material life changed to the rhythm of the economy and the environment. Someone engineered waterways. Someone tried to treat syphilis and malaria with talismans, metallic creams, cinchona or prayers. Someone amalgamated metals, minted money and tried to do something about the almost always fake five-sols coins. Someone tried to navigate ships in cloudy weather or under abnormal magnetic conditions. And, someone produced and reproduced maps. These someones had to work with or against quacks, earthquakes, propaganda, competition, new information, war, fresh goods, budgetary constraints or plague epidemics - real world people and phenomena that fell on a configuration of place and time that cannot be read from philosophical treatises alone. And, I believe these material factors should inform, without hope or fear of progress, the way we objectivize Ottoman science. I will try to illustrate these signs of change with two examples from the seventeenth and eighteenth centuries, but I first want to say a few words on why this has not yet taken root as standard practice.

5 Archives of the Prime Ministry, Ali Emiri, III. Ahmed 199. 
Part of the problem is the idealist and civilizationist approach that is still prevalent in the study of non-Western science. In the Ottoman case, many would still accept science to be part of the Islamic tradition and thus concede that either it required no material basis to survive or its material basis was constant until the nineteenth century. This view echoes an outdated political and economic history of the world-European colonization and the establishment of modern core-periphery relations - and has been the subject of sustained critique in recent years. ${ }^{6}$ Our profession has been a conduit for rebuilding Europe after World War II — still a ways off, looking at it in 2017 - which partly explains the emphasis on the Scientific Revolution and also its mirror image, civilizationism. Despite attempts to redistribute scientific credit fairly among the stakeholders, this approach has not led to peaceful cohesions outside of Europe either.

The idealist intellectual history in the Ottoman setting has led to an excessive focus on Muslim scholars and Islamic science. The equivocation of "Islamic science" with Ottoman science is problematic for several reasons. ${ }^{7}$ First, there was no such thing as the Islamic world in the early modern period. Two of the three major Muslim powers, the Safavids and the Ottomans, were engaged in unending physical, intellectual and confessional conflict from the sixteenth century onwards. ${ }^{8}$ Secondly, Ottoman scientific practitioners mostly wrote in Turkish - the imperial language and the vernacular of the western Ottoman Empire-which meant that they were not addressing the Islamic world but rather their fellow countrymen. ${ }^{9}$ These authors legitimized their use of Turkish by appealing to public utility or commonweal (nafia). Thirdly, both the sources and the ends of practiced science diverged from the textual legacy of the so-called Islamic tradition. There is an avalanche of Turkish translations from Latin, Persian and Arabic from the second half of the seventeenth century onwards, which suggests that Ottoman scientific practices were not the

6 Nelly Hanna, Artisan Entrepreneurs in Cairo and Early-Modern Capitalism (1600-180o) (Syracuse, 2011), 16-25.

7 Miri Shefer-Mosensohn, Science among the Ottomans (Austin, 2015), 13-16.

8 Markus Dressler, "Inventing Orthodoxy: Competing Claims for Authority and Legitimacy in the Ottoman-Safavid Conflict," in Legitimizing the Order, ed. Hakan Karateke and Maurus Reinkowski (Leiden, 2005), 151-176.

9 İhsan Fazlıoğlu, "Osmanlı Döneminde 'Bilim' Alanındaki Türkçe Telif ve Tercüme Eserlerin Türkçe Oluş Nedenleri ve Bu Eserlerin Dil Bilincinin Oluşmasındaki Yeri ve Önemi," Kutadgubilig 3 (2003): 151-184. 
automatic outgrowth of a single high-register intellectual tradition. ${ }^{10}$ Fourthly, we have no evidence to suggest that Ottoman scholars qua scholars (not as marketplace physicians, timekeepers, service-for-pay astrologers, accountants or courtiers) of the seventeenth and the eighteenth centuries actually did any science beyond repeating a well-worn canon of elementary textbooks. In other words, by the middle of the seventeenth century, A. I. Sabra's incisive analysis of science in medieval Islamic theology is no longer applicable." Finally, this over-Islamization excludes the non-Muslim subjects of the Ottoman Empire from the domain of science. Science used by early modern Muslims was not always Islamic science. And early modern Ottomans were not ethnic Turks wearing turbans.

Now, I want to offer a different picture that draws on a more up-to-date historiography of the Ottoman Empire to make early modern Ottoman science look, well, more Ottoman. First, the seventeenth-century Ottoman Empire competed with other empires on all possible fronts-the Safavids, the Venetian thalassocracy, the Russian Empire that was emerging from the Duchy of Muscovy and the Holy Roman Empire. ${ }^{12}$ Conquering and retaining as much territory as did the Ottomans had profound consequences for their empire. Ottoman imperialism was bidirectional, and you can read it in the science and the scholarship. The conquest of Mamluk territories in the sixteenth century introduced the Empire to Mamluk science and its institutions such as timekeeping houses, Ibn Khaldun's Muqaddima and prophetic medicine. ${ }^{13}$ The Ottoman-Venetian war, particularly the Ottoman conquest of Crete in 1669, created a formidable Greek commercial and political elite in Istanbul and ushered in a new era in philosophy and politics. ${ }^{14}$ The seventeenth-century Ottoman Empire was multi-ethnic and multi-denominational through and

10 Feza Günergun, "Ottoman Encounters with European Science, Sixteenth- and Seventeenth-Century Translations into Turkish," in Cultural Translation in Early Modern Europe, ed. Peter Burke and R. Po-chia Hsia (Cambridge, 2007), 192-211.

11 Abdelhamid I. Sabra, "Science and Philosophy in Medieval Islamic Theology," Zeitschrift für Geschichte der arabisch-islamischen Wissenschaften 9 (1994): 1-42.

12 Alan Mikhail and Christine Philliou, "The Ottoman Empire and the Imperial Turn," Comparative Studies in Society and History 54, no. 4 (2012): 721-745.

13 Shefer, 40, 47. See David King's works on Mamluk astronomy; on Ibn Khaldun see C. Fleischer, "Royal Authority, Dynastic Cyclism, and 'Ibn Khaldunism' in SixteenthCentury Ottoman Letters," Journal of Asian and African Studies 18, no. 3-4, (1983): 198-220.

14 Harun Küçük, "Natural Philosophy and Politics in the Eighteenth Century: Esad of Ioannina and Greek Aristotelianism at the Ottoman Court," Journal of Ottoman Studies 41 (2013): 125-159. 
through, and this diversity goes even deeper once we factor in the apparent uniform rule-compliance to Islam that religious conversion created. Recent studies have shown that forced and opportunistic conversions and career Muslims were quite common, especially at times of conquest and in elite circles. ${ }^{15}$ Thus, there were both explicit and hidden components to Ottoman demographic diversity, a diversity that cut across social strata and into science.

Ottoman diversity did not always lead to open-mindedness or to the sweetness and modesty of coexistence. ${ }^{16}$ In the realm of scientific translations of European texts, this has amounted to an inversion of George Basalla's model for the diffusion of modern science. ${ }^{17}$ It was not until the nineteenth century that European scientific theories received any noticeable credit in the Ottoman Empire despite the fact that Ottoman practitioners had been using European drug recipes, maps, ephemerides and instruments as well as new world plants and technologies at least since the mid-seventeenth century. ${ }^{18}$ Individuals who made this knowledge available —often merchants, Jewish and Christians diasporas, and adult converts to Islam-were hidden behind a Muslim veil. High-level Ottoman practitioners often appropriated the work of European scientists and treated their work as "passive repositories of data." And, earlymodern Europe was a massive global silo of data (in early modern terminology, practica or 'amel). Nominally-Muslim men of high rank routinely received credit for the work of others. This was not always the result of the ill intentions of the translator, who usually offered at least a vague indication of the sources. Still, we would not know the source texts for some seminal Ottoman works, such as The History of the West Indies or Cosmorama without the painstaking

15 Suraiya Faroqhi, "A Prisoner of War Reports: The Camp and Household of Grand Vizier Kara Mustafa Paşa in an Eyewitness Account," in Unfreie Arbeits- und Lebensverhältnisse von der Antike bis in die Gegenwart, ed. Elisabeth Herrmann-Otto (Hildesheim, 2005), 206-34; Marc Baer, Honored by the Glory of Islam (Oxford, 2008); Tijana Krstić, Contested Conversions to Islam (Stanford, 2011).

16 Edhem Eldem, "Ottoman Galata and Pera between Myth and Reality," in From "milieu de mémoire" to "lieu de mémoire," ed. Ulrike Tischler (München, 2006), 19-36.

17 George Basalla, “The Spread of Western Science," Science 156 (1967): 611-22.

18 B. Harun Küçük, "New Medicine and the Hikmet-i Tabi'iyye Problematic in EighteenthCentury Istanbul," in Texts in Transit in the Medieval Mediterranean, ed. Tzvi Langermann and Robert Morrison (College Park, 2016), 222-242; Sonja Brentjes, "Patchwork-The Norm of Mapmaking Practices for Western Asia in Catholic and Protestant Europe as well as in Istanbul between $155^{\circ}$ and 1750 ?" in Science between Europe and Asia, ed. Feza Günergun and Dhruv Raina (Dordrecht, 2011), 77-102. 
scholarship of Thomas Goodrich and Gottfried Hagen. ${ }^{19}$ Or, take Ibn Sallum. This titular founder of Ottoman new chemical medicine was relying on a palace physician known only as Nicholas for the translations of Oswald Croll's Basilica chymica and Daniel Sennert's De chymicorum. ${ }^{20}$

Summoning Steven Shapin's invisible technician here is not altogether out of place. ${ }^{21}$ The suppression of European, non-Muslim or low-social-status achievement both in history and historiography has also masked the true imperial character of Ottoman science. And, here is an issue of paramount historiographical and political import: Why do we rarely speak about Armenian, Jewish or Greek science as early modern Ottoman science? This question becomes all the more pressing once we take into consideration that non-Muslims played an important role in many technically open-ended practices from weaving to sapping, from engraving to minting, and from medicine to architecture.

Precisely because we are yet to reckon with this complicated legacy of seventeenth- and eighteenth-century Ottoman science, the nineteenth century often comes as a shock. Suddenly, we are faced with a Western modernity that has no corresponding early-modernity. The first Ottoman scientific societies in the nineteenth-century were multi-religious, multi-ethnic and emphasized utilitarian knowledge. And, the insistence on redistributing scientific credit to highlight medieval Muslim achievements-surely necessary, but also sometimes overdone - was part of the reactionary modernism of the nineteenth century Ottoman Empire. ${ }^{22}$

Now, let me turn to furnishing two examples that better illustrate how the history of Ottoman science could be rewritten in line with the new materialist historiography. Because I am a Europeanist who generally works with Turkish language sources, these examples will follow a certain pattern. I will take translations, the key objects of diffusion, and turn them over their heads to show how complex and hybrid early modern Ottoman science was, and how this science cut through social strata and went to the heart of the material life of early modern Ottomans.

19 Thomas Goodrich, The Ottoman Turks and the New World : a Study of Tarih-i Hind-i Garbi and Sixteenth-Century Ottoman Americana (Wiesbaden, 1990); Gottfried Hagen, Ein osmanischer Geograph bei der Arbeit. Entstehung und Gedankenwelt von Katib Celebis Gihannüma (Berlin, 2003).

20 Natalia Bachour, Oswaldus Crollius und Daniel Sennert im frühneuzeitlichen Istanbul (Freiburg im Breisgau, 2012).

21 Steven Shapin, “The Invisible Technician," American Scientist 77 (1989): 554-563.

22 Alper Yalçınkaya, Learned Patriots: Debating Science, State and Society in the NineteenthCentury Ottoman Empire (Chicago, 2014). 


\section{Copernicus for Tax Collectors?}

Copernicus, like Newton, acts like a telltale sign of the coming of modernity. For a long time, this has been a tiresome equivocation for those of us working outside the broadly Western context. ${ }^{23}$ Robert Westman's work has put the final nail on the coffin of the revolutionist readings of Copernicus. In the Ottoman Empire, Copernicus has also attracted quite a bit of attention. ${ }^{24}$ The first text expounding post-Copernican (and, in fact, anti-Copernican) European astronomy was İbrahim of Szigetvar's (fl.1660) Mirror of the Heavens at the Edge of Understanding (1662), a partial translation of Noël Durret's Nouvelle theorie des planetes (1635). ${ }^{25}$ My goal here is to show that this translation was related to astrological and taxation practices. It was anything but cosmological.

Calendars and taxation might seem like mundane issues, but that was far from the case. Recently, Saudi Arabia adopted the solar calendar to reduce the salaries of state employees without actually cutting their salaries. The Ottoman predicament in the early modern period was somewhat different but comparable. Dating early modern Ottoman documents is notoriously difficult because of the fiscal solar calendar that was adopted in 1677 . As an agrarian state, the Ottomans collected taxes once on the vernal equinox and once during harvest season. Yet, as a Muslim state, its salaries were scheduled on the Muslim lunar calendar. This was an enormous and occasionally lethal problem from a book-keeping perspective. The difference between the lengths of solar and lunar calendars meant that, once every thirty years or so, the state would pay a full year's salaries without no corresponding income. The solution proposed in $1677 / 1087$, the fiscal solar calendar, was a Julian calendar that has Muhammed's migration as its starting date. It dropped a year every thirty years to keep it in sync with the lunar calendar and each year started on the first of March. ${ }^{26}$ Alongside the emergence of fiscal reforms was the formation of a

23 Nathan Sivin, "Copernicus in China or, Good Intentions Gone Astray," Studia Copernicana 6 (1973): 63-122.

24 Ekmeleddin İhsanoğlu "Introduction of Western Science to the Ottoman World: A Case Study of Modern Astronomy (1660-1860)," in Transfer of Modern Science and Technology to the Muslim World, ed. Ekmeleddin İhsanoğlu (Istanbul, 1992); 67-120. Avner Ben Zaken, "Heavens of the Sky and the Heavens of the Heart: the Ottoman Cultural Context for the Introduction of post-Copernican Astronomy," British Journal for the History of Science 37, no. 1 (2004): 1-28.

25 Secencelü'l-Eflakfi Gayetü'l-İdrak, Kandilli ms 403. Noël Durret, Nouvelle theorie des planetes (Paris, 1635).

26 Richard B. Rose, "The Ottoman Fiscal Calendar," Middle East Studies Association Bulletin 25, no. 2 (1991): 157-167. 
centralized finance bureaucracy under Grand Vizier Fazll Ahmed's leadership, who was also Ibrahim of Szigetvar's employer. ${ }^{27}$

Although the Ottomans had been struggling with their agrarian-Muslim predicament since the fifteenth century, collection of cash taxes was not of paramount concern in the fifteenth and sixteenth centuries. In the seventeenth century, the increase in the number of salary-drawing janissaries and the abandonment of agricultural lands as a response to inclement weather and political disorder made the cash treasury a much more vital element of the Ottoman administration. The widespread circulation of debased European coins exacerbated the empire's cash-flow problem. ${ }^{28}$

I will publish a study of the Mirror of the Heavens in the future, but here, I want to point out several textual and contextual issues that show what I mean by the connection between science and the economy in the Ottoman Empire. Scholars have focused largely on the cosmological and modernizing features of this text. This choice begins to seem problematic upon closer inspection of the sole surviving manuscript copy of the Turkish and Arabic translation of Noel Durret's Nouvelle theorie des planetes, Kandilli Ms 403. İbrahim of Szigetvar did not actually translate any of the new planetary theories, but rather Durret's equinoctial problemata and solar-lunar mean motion tables as well as lists of planetary conjunctions and oppositions. ${ }^{29}$ Forming the bulk of the twenty-nine sheet text prepared by Ibrahim were cherry-picked discussions that focused largely on calendrical matters, with a sidelong glance at practical astrology. ${ }^{30}$

A second challenge against the cosmological interpretation involves the nowfamous visual of the Ptolemaic, Tychonic and Copernican systems. Not only was this diagram not in the Nouvelle theorie, which did not include any discussion of physical astronomy, but it is also hard to tell if Ibrahim Efendi drew the Copernican visual. My guess is that it was drawn subsequently by another who had the book in his possession. The latest astronomical annotation on the diagram

27 Linda T. Darling, "Public Finances: The Role of the Ottoman Centre," in The Cambridge History of Turkey, vol. 3: The Later Ottoman Empire, 1603-1839, ed. Suraiya Faroqhi (Cambridge, 2006), 123.

28 Metin Kunt, The Sultan's Servants: The Transformation of Ottoman Provincial Government, 1550-1650 (New York, 1983), 79-80. Halil Sahillioğlu, "Sıvış Year Crises in the Ottoman Empire," in Studies in the Economic History of the Middle East: From the Rise of Islam to the Present Day, ed. M. A. Cook (London, 1970), 230-54.

29 Planetary conjunction-opposition tables constituted a fifth of the volume. See $5 \mathrm{a}, 11 \mathrm{a}, 16 \mathrm{~b}$, 21a.

30 A. Tunç Şen, "Rasattan Takvime: xv/Xvi. Yüzyll Osmanlı Dünyasında Astrolojinin Yeri Üzerine Bazı Gözlemler," Osmanlı'da İlim ve Fikir Dünyası, ed. Ömer Mahir Alper and Mustakim Arıcı (İstanbul, 2015), 227-250. 
is dated 1694-probably long after Ibrahim died-where the annotator speaks about a major fire, followed by a minor earthquake and a fire during that year $(\mathrm{AH}$ 1105) when Mars and Jupiter were in a conjunction. Astrological annotations on the first page go all the way to 1703. Also odd about the illustration are the planetary symbols, which Ibrahim never used anywhere else in the text. Furthermore, this diagram is not attached to the text in the way other diagrams were. While the movement or the lack thereof of the sun bears on the technical content of the text, Ibrahim was clear from the outset, as was Durret, that both the text and the tables model take the earth to be stationary and at the center of the universe.

There are also contextual reasons for us to favor a primarily calendrical and indirectly economic reading of this text over the cosmological reading. Ibrahim of Szigetvar was a registrar who travelled with the Ottoman army. His title, "tezkireci," suggests that his main line of work was making a record of taxes levied and services received. ${ }^{31}$ There was an important connection between calendars and tax collection, which in turn pointed to Ibrahim's quotidian concerns.

Ibrahim was not alone in his calendrical interests. Since the sixteenth century, at least some Ottoman scribes used zodiacal designations when dating financial documents. ${ }^{32}$ In the late seventeenth century, the scribal-calendrical connection became even more explicit. A prime example is Şemseddin Ahmed's (d.1708) famous work, Using the Quadrant in the Science of the Stars. ${ }^{33}$ Ahmed was a scholar who also wrote on the calendrical and time-keeping aspects of astronomy. He had earned his epithet "Ishak Hocasi" or "Ishak's instructor" because he taught astronomy to Ishak, another tax-registrar working under Fazll Ahmed Paşa. ${ }^{34}$ Using the Quadrant is about solar and lunar calculations using a simplified astrolabic quadrant, and even includes instructions on making a perpetual lunar-solar calendar. While it will take some more work to establish the connection between Mirror of the Heavens and calendar reform, this is too much smoke for there to be no fire.

The image of the astronomer as a practical man of modest means runs counter to the more glamorous image of Islamic astronomy before the seventeenth century. Most importantly, Ibrahim's text points to a practical register that has remained hitherto unexplored, while theory remains king in the historiography of Ottoman astronomy. Combined with anecdotal evidence on the role and function of Ottoman timekeeping houses, which frequently worked with and for Ottoman merchants and sailors, the picture that we get is quite a different kind

31 Linda T. Darling, Revenue-Raising and Legitimacy: Tax Collection and Finance Administration in the Ottoman Empire, 1560-1660 (Leiden, 1996).

32 Nejat Göyünç, "xvi. Yüzyllda Ruûs ve Önemi," Tarih Dergisi XVII, no. 22 (1967): 17-34.

33 Kandilli ms 5.

34 Reşat Öngören, "Ishak Hocası," TDV İslam Ansiklopedisi, vol. 22: 533-4. 
of modernity-one that is not about Copernicus but about consumable astronomical knowledge that had a close relationship with the economy and the state.

\section{Global, Mercantile, Sacred: The Making of the Eighteenth-Century Ottoman Qibla Compass}

The magnetic compass points due North - this is not exactly true and it's definitely not true everywhere- and it does so for reasons we did not understand until the twentieth century. It was a mystery device for the majority of known history. In this mini-study, I want to look at the Ottoman prayer compass, a common eighteenth-century device with a deep global history. My argument is comparable to that of Edgar Zilsel's study of Gilbert's De Magnete - arguably the first work to merge scholastic and empirical knowledge in the European setting. The Ottoman prayer compass was a mercantile instrument that turned into a devotional object through an interaction between intellectuals and craftsmen..$^{35}$

The qibla compass has a mercantile-maritime genealogy and not an "Islamic tradition"-type genealogy. Eighteenth-century Ottomans used two different terms for the compass: busula, from the Italian word bussola, and kıblenüma, a Persian word that meant both a south-indicator and a qibla-indicator. The medieval Arabic word for the water-filled compass bowl (tasa) had already gone out of currency. ${ }^{36}$ The most famous among the kıblenümas is Armenian craftsman Petros Baronyan's device from 1738, which had a map (from Gibraltar to China), a miniature of Mecca, a quick user manual, as well as a table for the declination values for various cities around the world. It is the most sophisticated qibla compass ever built and also the first such device to include values for magnetic declination. ${ }^{37}$

Of course, magnetism was nothing new to anyone in 1738 . The compass was already a popular device among Ottoman merchants and sailors by the seventeenth-century. ${ }^{38}$ Magnetism was also part and parcel of what Giancarlo

Edgar Zilsel, "The Origins of William Gilbert's Scientific Method," Journal of the History of Ideas 2, no. 1 (1941): 1-32. For a historiographical projection of Zilselian analysis, see Peter Dear, "Towards a Genealogy of Modern Science," in The Mindful Hand, 431-442.

36 Petra G. Schmidl, "Two Early Arabic Sources on the Magnetic Compass," Journal of Arabic and Islamic Studies 1 (1977-8): 81-132.

37 Feza Günergun, "La traduction de l'Abrégé de la sphère de Jacques Robbe, géographe du Roi de France par Petros Baronian, drogman à Istanbul: Cem-nümâ fi fenn el-coğrafya," $L a$ Révolution française 12, no. 2 (2017); http://lrf.revues.org/1841.

38 Aṛak'el of Tabriz, Book of History, George A Bournoutian, trans. (Costa Mesa, CA, 2010), 464. Süheyl Ünver, "Osmanlı Türkleri İlim Tarihinde Muvakkithaneler," Atatürk Konferansları V (Ankara, 1975), 229. 
Casale has called the Ottoman Age of Exploration. We can read this through the Ottoman histories and mythologies surrounding this device, most of which point to India. As early as the mid-sixteenth century, Ottoman Admiral Seydi Ali Reis, who used the compass avidly as he navigated around Surat, felt the need to develop an empirical protocol, using at least two compasses against one another as "witnesses" to improve the instrument's reliability. ${ }^{39}$ His Book of the [Indian] Ocean was comparable to the works of contemporary Portuguese and Spanish cosmographers, who were roaming the vicinity, and combined Ali's theoretical knowledge of high Islamic astronomy and his practical engagement with the compass. ${ }^{40}$

What was novel in 1738 was the philosophical legitimacy of the compass, a fresh explanation for the secular variation in the magnetic north, and the soaring interest in this humble device. And, it was a motley crew of rejects from mainstream European history that ultimately turned the compass, a practical maritime instrument, into a devotional and philosophical instrument in the early 1730s. This network had two key actors, Johann Friedrich Bachstrom (1686-1742) and Ibrahim Müteferrika (?-1745), but it extended to include many other individuals at both ends and in between. Bachstrom was a Polish physician and a Pietist missionary who stayed in Istanbul between 1728 and 1730 . Ibrahim Müteferrika was an ex-Socinian diplomat, printer and geographer who had been serving Sultan Ahmed III since the 1710s.

The key magnetic controversy that created the qibla compass with deviation values took place in 1730. Ibrahim Müteferrika and Istanbul's timekeepers proposed different orientations for the mosque the Ottoman admiral wanted to build in Bebek:

This poor man has tried to use a compass in determining the qibla for the mihrab of the new Admiral Mustafa Pasha mosque in Bebek. Many learned men came together, some bearing compasses, some bearing quadrants and others astrolabes. What we saw on the compass never matched what they read on the astronomical instruments. So, the learned men decided to disregard the compass and the mihrab was built based on the calculations of the astronomers. This made us, the industrious men, work even harder to determine the true direction [ ${ }^{\wedge}$ of the qibla] and they used a vertical reckoning device with a large needle. We tested the device

39 Himmet Büke, "Seydi Ali Reis—Kitabü'l-Muhit," (Unpublished mA Thesis, Pamukkale University, 2010).

40 María Portuondo, Secret Science: Spanish Cosmography and the New World (Chicago, 2009). 
and figured that the aforementioned disagreement was on account of a Westward deviation of 11.5 degrees. ${ }^{41}$

It was this encounter that motivated Müteferrika to publish Magnetic Effluvia more than a year later. Pietist Christoph Eberhard's Versuch einer magnetischen theorie, which in turn reported on Francis Noël's (sJ) observations from the Indian and Chinese open seas, formed the bulk of Müteferrika's book on magnetism - significant facts that Müteferrika never shared with his readers. Müteferrika's Magnetic Effluvia also expounded a particularly toothless French version of Cartesian philosophy, which I will not delve into here. What matters is that Magnetic Effluvia presented an empirical account of how, when and where the compass worked - it was the first philosophical explanation for the compass in the Ottoman context. What the history of the Ottoman qibla compass reveals is the deep globality embedded in a mundane object. And, like the calendar, the compass also occupied an important role in the everyday economic and devotional life of the Ottomans.

\section{A Preliminary Conclusion}

In this brief paper, I have tried to outline a case for the materialist interpretation of early modern Ottoman science. The mini studies I present here are provisional and preliminary, but they showcase certain methodological elements for the emerging historiography of global science. The examples implicate the Scientific Revolution itself. Early modern European natural knowledge that was useful, global, and to a certain extent, standardized elsewhere, has little to do with the canonical interpretation of the Scientific Revolution. I am proposing a different model of thinking about early modern science based on the Ottoman experience: European knowledge came in as data and was folded into existing practices and debates. If European knowledge contributed to practices that already existed elsewhere, what does that say about the uniqueness and inventiveness of Europe? This paper also points to the potential of histories of science beyond the Western context in revising the narrative of the Scientific Revolution, which, for the most part, has been a self-enclosed story with an increasingly localist and culturalist emphasis.

41 İbrahim Müteferrika "Printer's Preface" to Katip Çelebi, Cihannüma = Cosmorama (Istanbul, 1732). 